\title{
Mycorrhizal dependency of mangaba tree under increasing phosphorus levels
}

\author{
Júlio Alves Cardoso Filho(1), Eurico Eduardo Pinto de Lemos ${ }^{(1)}$, Tania Marta Carvalho dos Santos ${ }^{(1)}$, \\ Luis Carlos Caetano ${ }^{(2)}$ and Marco Antonio Nogueira( ${ }^{(3)}$
}

\begin{abstract}
(1)Universidade Federal de Alagoas (Ufal), Departamento de Fitotecnia e Fitossanidade, BR 104 Norte, Km 85, CEP 57100-000 Rio Lago, AL, Brazil. E-mail: julioalvescardosofilho@yahoo.com.br, eepl@uol.com.br, tmcs@ceca.ufal.br(2)Ufal, Departamento de Química. E-mail: Icc@qui.ufal.br (3)Universidade Estadual de Londrina, Departamento de Microbiologia, Caixa Postal 6001, CEP 86051-990 Londrina, PR, Brazil. E-mail: nogueira@uel.br
\end{abstract}

\begin{abstract}
The objective of this study was to evaluate the mycorrhizal dependency of mangaba tree (Hancornia speciosa) plantlets, under increasing levels of phosphorus fertilization. The experimental design was completely randomized in a $4 \times 5$ factorial arrangement with three mycorrhizal fungi inocula - Gigaspora margarita, Glomus etunicatum, or a pool of native mycorrhizal fungi (Acaulospora longula, Glomus clarum, Gigaspora albida, Paraglomus sp.) -, and a nonmycorrhizal control, in combination with five levels of phosphorus applied to the substrate: $0,25,50,75$, and $100 \mathrm{mg} \mathrm{kg}^{-1}$. After 180 days of growth, plantlets with inoculation of native mycorrhizal pool produced more shoot and root dry biomass and had higher shoot phosphorus content and accumulation. The noninoculated control showed the lowest values, independently of the phosphorus level. The highest relative mycorrhizal dependency occurred with the inoculation of native mycorrhizal fungi. Plants with mycorrhizal fungi did not respond to phosphorus addition above $50 \mathrm{mg} \mathrm{kg}^{-1}$. Mangaba tree is highly dependent on mycorrhiza, but the degree of dependency varies according to phosphorus levels and fungal inocula. In general, mangaba tree is more responsive to mycorrhizal fungi inoculation than to phosphorus addition.
\end{abstract}

Index terms: Gigaspora margarita, Glomus etunicatum, Hancornia speciosa, biofertilizers, native mycorrhizal fungi, phosphorus nutrition.

\section{Dependência micorrízica de mangabeira em doses crescentes de fósforo}

\begin{abstract}
Resumo - O objetivo deste trabalho foi avaliar a dependência micorrízica de mudas de mangaba (Hancornia speciosa), em doses crescentes de fósforo. O delineamento experimental foi inteiramente casualizado, em arranjo fatorial $4 \times 5$ com três inóculos de fungos micorrízicos - Gigaspora margarita, Glomus etunicatum, ou uma mistura de espécies de fungos micorrízicos nativos (Acaulospora longula, Glomus clarum, Gigaspora albida e Paraglomus sp.) -, e um controle não micorrízico, combinados a cinco doses de fósforo no substrato: 0, 25, 50, 75 e $100 \mathrm{mg} \mathrm{kg}^{-1}$. Após 180 dias, as mudas com inoculação dos fungos micorrízicos nativos produziram mais biomassa seca de parte aérea e raízes e apresentaram maior concentração e acúmulo de fósforo na parte aérea. O controle sem inóculo apresentou os menores valores, independentemente da dose de fósforo. A maior dependência micorrízica relativa ocorreu com a inoculação de fungos micorrízicos nativos. Plantas com inoculação micorrízica não responderam à adição de fósforo, em doses acima de $50 \mathrm{mg} \mathrm{kg}^{-1}$. A mangabeira é altamente dependente de micorrizas, mas o grau de dependência varia de acordo com os níveis de fósforo e com os inóculos fúngicos. Em geral, a mangabeira é mais responsiva à inoculação com fungos micorrízicos do que à adição de fósforo.
\end{abstract}

Termos para indexação: Gigaspora margarita, Glomus etunicatum, Hancornia speciosa, biofertilizantes, fungos micorrízicos nativos, nutrição fosfatada.

\section{Introduction}

The mangaba tree (Hancornia speciosa Gomes) (Apocynaceae) is a native Brazilian fruit, which occurs naturally on low-fertility soils in the coastal areas and in the biome Cerrados (Aguiar Filho et al., 1998). Due to increasing deforestation and urbanization of coastal areas, this species has had its natural germplasm bank severely reduced. In Northeastern Brazil, an important pulp market has developed based on exotic tropical fruits, 
including mangaba. Propagation of elite mangaba trees is desirable to increase the productivity in orchards, but the use of seeds or vegetative methods is very laborious (Parente \& Carmona, 1988). In addition, very few plants survive in the nursery and in the field, after transplanting, when the mortality may reach $60 \%$ (Sano \& Fonseca, 2003).

It has been reported that dependency on mycorrhiza varies between and within plant species (Cavalcante et al., 2001; Zangaro et al., 2007) and those with shorter root length and greater diameter usually benefit more from mycorrhizal symbiosis (Zangaro et al., 2005). Morphological root traits, such as root geometry, rate of root growth, density and length of root hairs have often been used as indicators of mycorrhizal dependency (Zangaro et al., 2007).

Inoculation with arbuscular mycorrhiza (AM) seems to be an interesting tool to select elite mangaba genotypes and to help in the domestication and improvement of recalcitrant species, given that $H$. speciosa has shown to be highly responsive do AM, mainly in low-fertility soils (Costa et al., 2005). Thus, it is important to know the dependency of $H$. speciosa on AM, for seedlings production purposes and for the use of effective AM inocula during the nursery phase. Arbuscular mycorrhiza can reduce the need for fertilizers and anticipate the time for transplantation of plantlets produced in nurseries (Costa et al., 2003). In addition, more vigorous plantlets could be obtained, increasing the capacity to withstand the stress caused by transplantation from the nursery to the field.

The objective of this study was to evaluate the mycorrhizal dependency of mangaba tree (Hancornia speciosa) plantlets, under increasing levels of $\mathrm{P}$ fertilization.

\section{Materials and Methods}

The experimental design was completely randomized in a $4 \times 5$ factorial arrangement, consisting of three mycorrhizal inocula: Gigaspora maragarita Becker \& Hall, Glomus etunicatum Becker \& Gerdemann, or a pool of native AM fungus (Acaulospora longula Spain \& Schenck, Glomus clarum Nicol. \& Schenck, Gigaspora albida Schenck \& Smith and Paraglomus sp.), and a nonmycorrhizal control, in combination with five $\mathrm{P}$ levels in the growing substrate: 0, 25, 50, 75 and $100 \mathrm{mg} \mathrm{kg}^{-1}$, with five replicates.
Seeds from mature mangaba fruits were collected from native trees at coastal areas with "restinga" vegetation (called "tabuleiros" in the Brazilian Northeast), and were surface-sterilized with $2.5 \%(\mathrm{v} / \mathrm{v})$ sodium hypochlorine for $20 \mathrm{~min}$. Seeds were, then, rinsed in distilled sterile water and germinated in sterile Petri dishes with moistened filter paper in the dark at $28^{\circ} \mathrm{C}$. Five days after germination, seedlings were moved to asbestos trays containing autoclaved river sand, and were kept in greenhouse for more 17 days, when they were transplanted to the pots.

The soil used in the experiment was a low-fertility Xanthic Ferralsol (FAO, 1994) collected at 0-20 cm depth ( $\mathrm{pH} \mathrm{CaCl}_{2}, 4.2$; organic matter, $10.9 \mathrm{~g} \mathrm{~kg}^{-1}$; $\mathrm{P}$, $4 \mu \mathrm{g} \mathrm{g}^{-1} ; \mathrm{S}, 3.7 \mu \mathrm{g} \mathrm{g}^{-1} ; \mathrm{K}, 0.6 \mathrm{mmol} \mathrm{dm}{ }^{-3} ; \mathrm{Ca}$, $1.5 \mathrm{mmol} \mathrm{dm}^{-3}$; $\mathrm{Mg}, 0.2 \mathrm{mmol} \mathrm{dm}^{-3}$ and $\mathrm{H}+\mathrm{Al}$, $41 \mathrm{mmol} \mathrm{dm}^{-3}$; micronutrients in $\mu \mathrm{g} \mathrm{g}^{-1}: \mathrm{B}, 0.2 ; \mathrm{Cu}, 0.1$; Fe, 43.2; Mn, 8; Zn, 0.3). The soil texture was: 830, 40 and $130 \mathrm{~g} \mathrm{~kg}^{-1}$ of sand, silt and clay, respectively. The soil was mixed with washed river sand $(1: 1 \mathrm{v} / \mathrm{v})$ and autoclaved at $121^{\circ} \mathrm{C}$ for 1 hour in order to eliminate the native mycorrhizal fungi.

Polyethylene pots $\left(5 \mathrm{dm}^{3}\right)$ were filled with $4 \mathrm{~kg}$ of the mixture and received dolomitic lime (1.58 $\mathrm{g}$ per pot) in order to raise the $\mathrm{pH}\left(0.01 \mathrm{M} \mathrm{CaCl}_{2}\right)$ to 6 , based on incubation method. Phosphorus was mixed into the soil as simple superphosphate $(8.3 \% \mathrm{P} ; 18.8 \% \mathrm{Ca} ; 12.6 \% \mathrm{~S})$ at four different rates corresponding to $25,50,75$ or $100 \mathrm{mg} \mathrm{kg}^{-1}$ of $\mathrm{P}$, besides a $0 \mathrm{P}$ treatment. Afterwards, all pots received $\left(\mathrm{mg} \mathrm{kg}^{-1}\right)$ : $\mathrm{N}$ (80 as $\left.\mathrm{NH}_{4} \mathrm{NO}_{3}\right), \mathrm{K}$ (150 as $\mathrm{K}_{2} \mathrm{SO}_{4}$ ), $\mathrm{Zn}\left(2\right.$ as $\left.\mathrm{ZnSO}_{4} \cdot 7 \mathrm{H}_{2} \mathrm{O}\right)$, B (0.5 as $\left.\mathrm{H}_{3} \mathrm{BO}_{3}\right)$ and $\mathrm{Mo}\left(0.1\right.$ as $\left.\mathrm{H}_{2} \mathrm{MoO}_{4}\right)$. Nitrogen $\left(\mathrm{NH}_{4} \mathrm{NO}_{3}\right)$ was supplied again, as solution, with $20 \mathrm{mg}$ per pot, for four times, during plant growth in greenhouse: at transplanting and 30, 60 and 90 days after; total additional $\mathrm{N}$ was $80 \mathrm{mg}$ per pot.

Uniform plantlets with two pairs of true leaves, and with $10 \mathrm{~cm}$ high, were transplanted to the pots containing previously fertilized soil.

The AM inocula in pure culture (G. margarita or G. etunicatum) were multiplied for 120 days in pots grown with Panicum maximum Jacq., and consisted of $50 \mathrm{~g}$ of sandy soil containing approximately 1,650 spores of each AM fungus. Native AM inocula were taken from natural sites at "restinga" vegetation and were also multiplied in $P$. maximum as trap plant. After multiplication, the density of native spores was about 1,800 in $50 \mathrm{~g}$ of soil, with prevalence of $A$. longula, about four times higher than the other AM species (G. clarum, 
G. albida and Paraglumus sp.), which, in turn, occurred in almost the same proportion. The mycorrhizal inocula $(50 \mathrm{~g})$ were placed in a band approximately $5 \mathrm{~cm}$ below the soil surface, while the nonmycorrhizal control received $50 \mathrm{~g}$ of soil grown with $P$. maximum without AM fungi.

The experiment was conducted under greenhouse, at Universidade Federal de Alagoas. Noncontrolled temperature and relative humidity were recorded by a digital thermohygrometer; minimum and maximum temperature values ranged from $21.4^{\circ} \mathrm{C}$ (night) to $37.9^{\circ} \mathrm{C}$ (day); irradiance was $1,200 \mu \mathrm{mol} \mathrm{m} \mathrm{m}^{-2} \mathrm{~s}^{-1}$; relative humidity ranged from 60 to $90 \%$; and the day length was 13 hours. The soil moisture was controlled by weighing and daily irrigation with distilled water, in order to maintain $80 \%$ of the water holding capacity.

Plants were harvested 180 days after transplanting, the shoots and roots were collected and the dry biomasses weighed, after drying at $70^{\circ} \mathrm{C}$ for 48 hours. Relative mycorrhizal dependency (RMD) was calculated according to Plenchette et al. (1983): [(M-NM)/ $\mathrm{M}] \mathrm{x} 100$, in which: $\mathrm{M}$ is the total dry biomass of mycorrhizal plants; NM is the total dry biomass of nonmycorrhizal plants. The degrees of RMD were classified according to Habte \& Manjunath (1991). Roots were carefully washed in tap water and cut into $1 \mathrm{~cm}$ long segments. A sample of $1 \mathrm{~g}$ of fresh root of each plant was clarified with KOH (Phillips \& Hayman, 1970), and stained with acid fuchsin (Kormanik \& McGraw, 1982). The percentage estimation of the mycorrhizal root colonization was based on the gridline intersection method (Giovannetti \& Mosse, 1980). Phosphorus concentration in shoots was determined colorimetrically (Murphy \& Riley, 1962) in nitric-perchloric acid digests.

Data were submitted to the analysis of variance, using the general linear models procedure of the SAS, followed by regression analysis (SAS Institute, 1996). Percentage values of mycorrhizal root colonization were transformed to $\operatorname{arc} \sin (\mathrm{x})^{0.5}$ prior to analysis.

\section{Results and Discussion}

Shoot and root dry biomasses increased due to mycorrhizal colonization at all $\mathrm{P}$ levels, mainly in plants with inoculation of native AM pool (NP) (Figure $1 \mathrm{~A}$ and B). The lowest dry biomasses for both shoot and roots were found in the nonmycorrhizal control plants (Co), irrespective to P levels. In plants infected with the native $\mathrm{AM}$ pool, maximum shoot and root biomasses were reached above $50 \mathrm{mg} \mathrm{kg}^{-1}$ of added $\mathrm{P}$ (around $65 \mathrm{mg} \mathrm{kg}^{-1}$ of $\mathrm{P}$ ), the maximum point described by the quadratic regression adjustment, followed by a decrease thereafter. Considering the nonmycorrhizal plants, the increase of $\mathrm{P}$ levels in the soil increased only slightly the shoot and root dry biomasses, contrary to the observed for mycorrhizal plants. While plants infected with G. etunicatum and G. margarita responded at an intermediate level to $\mathrm{P}$ addition, the native mycorrhizal pool caused a more intense plant response to P. Previous report showed that increase of $\mathrm{P}$ levels in the soil suppressed mangaba plantlets response to Gigaspora albida, while G. etunicatum showed no effect at any $\mathrm{P}$

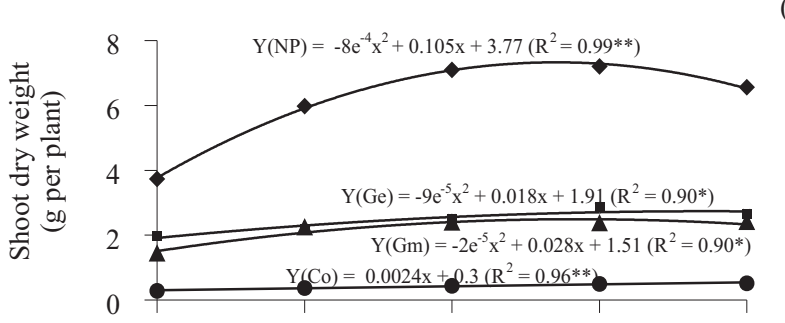

(B)

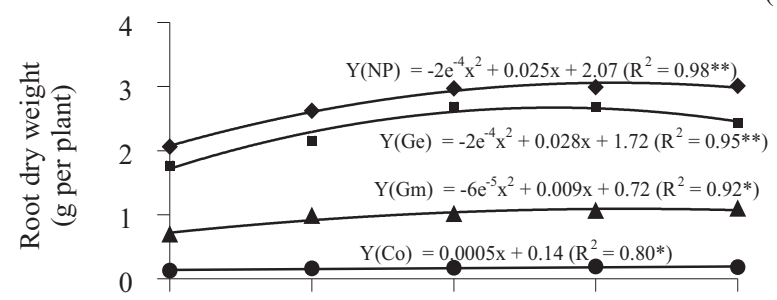

(C)

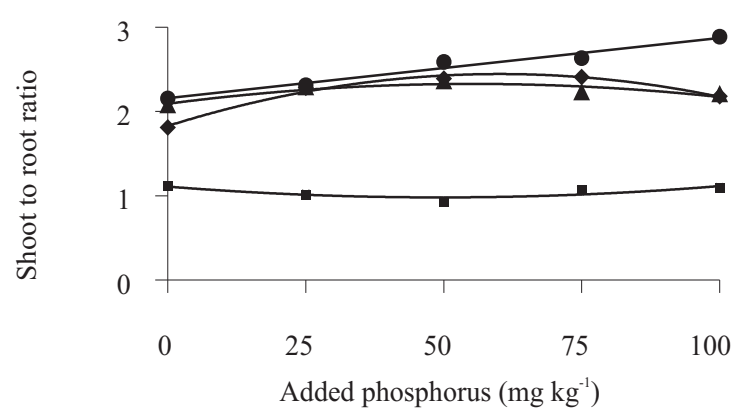

Figure 1. Shoot (A) and root (B) dry biomass, and shoot to root ratio $(\mathrm{C})$ of mangaba tree grown in a sterilized soil with increasing levels of phosphorus and mycorrhizal treatments: native pool, NP ( $\bullet)$; Glomus etunicatum, Ge ( $\mathbf{\square})$; Gigaspora margarita, $\mathrm{Gm}(\boldsymbol{\Delta})$; and nonmycorrhizal mangaba plants, Co $(\bullet)$. ${ }^{*}$ and $* *$ Significant regressions at 5 and $1 \%$ probability level, respectively. 
level ranging from 3 to $183 \mathrm{mg} \mathrm{dm}^{-3}$ (Costa et al., 2005). In the present work, shoot dry weight increased up to $50 \mathrm{mg} \mathrm{kg}^{-1}$, depending on the mycorrhizal inoculum.

The behavior of root dry biomass was similar to the reported for shoots, except for G. etunicatum which increased root biomass to levels comparable to plants infected with the native mycorrhizal pool. This fact changed biomass allocation between shoots and roots: plants colonized by G. etunicatum showed a shoot to root ratio around 1 , while in the other treatments, including control plants, the shoot to root ratio was about 2 (Figure 1 C).

The increase of soil P levels tended to increase the shoot to root ratio only in the control, whereas in the mycorrhizal treatments it remained more stable. Many researchers have shown benefits of inoculations with AM in perennial crops such as citrus (Nogueira \& Cardoso, 2006), coffee (Tristão et al., 2006) and passion fruit (Cavalcante et al., 2001). In general, these effects are more evident when soil $\mathrm{P}$ level is deficient. Nevertheless, even with increasing $P$ levels up to $100 \mathrm{mg} \mathrm{kg}^{-1}$, in the present study, the plant growth response to AM was only slightly decreased.

Plants infected with the native AM pool (NP) experienced a shoot growth depression at the higher $\mathrm{P}$ levels. Even in the less effective symbioses (Ge or $\mathrm{Gm}$ ), plants tended to show a growth depression, as illustrated by the quadratic regressions adjustments. Under excessive $P$, the symbioses may be impaired and induce growth depression in plant likewise in citrus (Nogueira $\&$ Cardoso, 2006). Although growth depression in citrus had been verified only at $1,000 \mathrm{mg} \mathrm{kg}^{-1}$ of $\mathrm{P}$, mangaba plantlets exhibited this phenomenon just above $50 \mathrm{mg} \mathrm{kg}^{-1}$, showing that the mycorrhizal symbiosis in mangaba is much more sensitive to $P$ than in citrus. Such depression is generally attributed to the cost of the symbiosis, mainly with regard to the drain of carbohydrates from the host in a condition that the benefit from $\mathrm{P}$ uptake, mediated by the fungal partner, is lower than the C cost (Graham, 2000). To our knowledge, this is the first report on growth depression in mycorrhizal mangaba plantlets under excessive $\mathrm{P}$.

The relative micorrhizal dependency (RMD) of mangaba plantlets varied with the AM inocula and P levels, but was considered very high at all P levels and mycorrhizal inoculum types (Habte \& Manjunath, 1991), reaching more than $75 \%$ of dependency on AM (Figure 2). The RMD of mangaba in the treatments with pure inocula ranged from 78 to $85 \%$, while the RMD with native AM pool was far above, around $93 \%$. When inoculation was with native fungal pool, the RMD of $H$. speciosa increased in comparison to the inoculation with sole mycorrhizal species, independently of the $\mathrm{P}$ level.

Phosphorus levels had little influence on the RMD, which indicates high mangaba dependence on AM, even under higher P levels in the soil. Mycorrhizal dependency varies with plant species (Zangaro et al., 2007), soil nutrient levels (Costa et al., 2005; Zangaro et al., 2007), soil type (Van der Reijden \& Kuyper, 2001), as well as with the mycorrhizal species (Costa et al., 2003, 2005; Nogueira \& Cardoso, 2007). The degree of RMD was weakly dependent on soil P level, but was strongly dependent on the mycorrhizal species. This observation is very important for selection of more effective AM inocula, in order to improve mangaba seedlings production in nursery.

Root colonization by G. margarita or G. etunicatum reached different levels and declined with increasing $P$ levels (Figure 3). Conversely, P levels did not affect mycorrhizal colonization, when the inoculum was the native AM pool. It was observed that G. margarita and G. etunicatum presented their highest root colonization between 0 and $25 \mathrm{mg} \mathrm{kg}^{-1}$ of added P. However, native AM presented average root colonization of $77 \%$, considering all $\mathrm{P}$ levels. The higher colonization and the absence of $\mathrm{P}$ levels effect, in the treatment with the

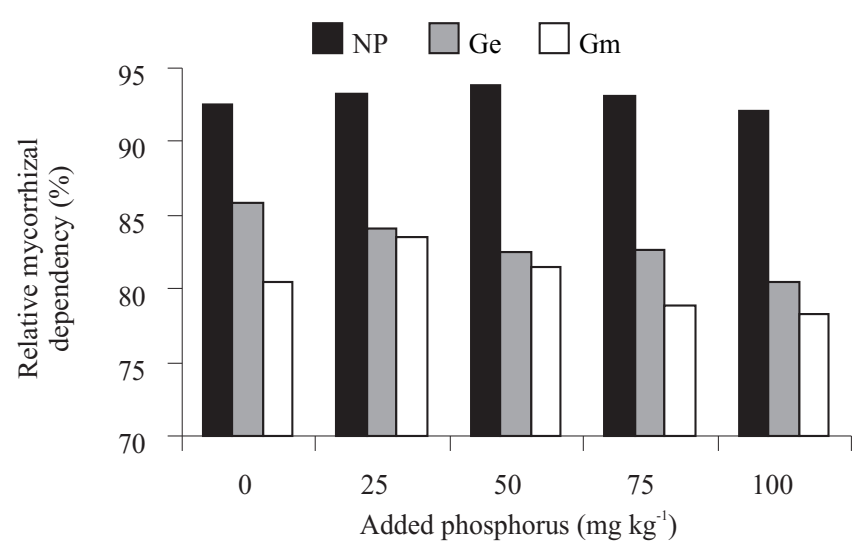

Figure 2. Relative mycorrhizal dependency (RMD) of mangaba tree inoculated with AM, in a sterilized soil with increasing levels of phosphorus. Native pool, NP; Glomus etunicatum, Ge; Gigaspora margarita, Gm. RMD was calculated as follows: [(M-NM)/M] x 100, in which $\mathrm{M}$ is the total dry biomass of mycorrhizal plants; NM is the total dry biomass of nonmycorrhizal plants (Plenchette et al., 1983). 
native $\mathrm{AM}$ pool, can be attributed to the higher diversity of AM in this treatment, containing species more tolerant to $\mathrm{P}$ fertilization levels. Costa et al. (2005) showed that the increase of $\mathrm{P}$ levels did not affect the amount of arbuscules in the roots of mangaba trees, when the soil was not sterilized and contained high diversity of native AM. The native AM are often more adapted to local edaphic conditions, and their competitiveness may differ according to soil conditions and soil-plant-endophyte association. In addition, the AM have different strategies for root colonization. For example, the Gigasporaceae use to have less root colonization but produce more external mycelium, in an opposite fashion to the generally observed for the Glomeraceae (Hart \& Reader, 2002). In fact, in the present work, despite the external mycelium had not been accessed, lower root colonization was observed for G. margarita in relation to G. etunicatum, as previously surveyed.

In general, $\mathrm{P}$ addition in the soil increased shoot $\mathrm{P}$ concentration and accumulation more expressively in the mycorrhizal plants than in the nonmycorrhizal control (Figure $4 \mathrm{~A}$ and B). Plants infected with G. margarita showed no significant differences in the shoot $\mathrm{P}$ concentration along the $\mathrm{P}$ levels. The greater shoot $\mathrm{P}$ concentration and accumulation, verified in mycorrhized mangaba compared to the nonmycorrhizal plants, can be explained by several mechanisms used by the mycorrhizal external mycelium for a better soil exploration (Nogueira \& Cardoso, 2007) and modifications in host plant physiology (Graham, 2000). The values of $\mathrm{P}$ concentrations are slightly higher than

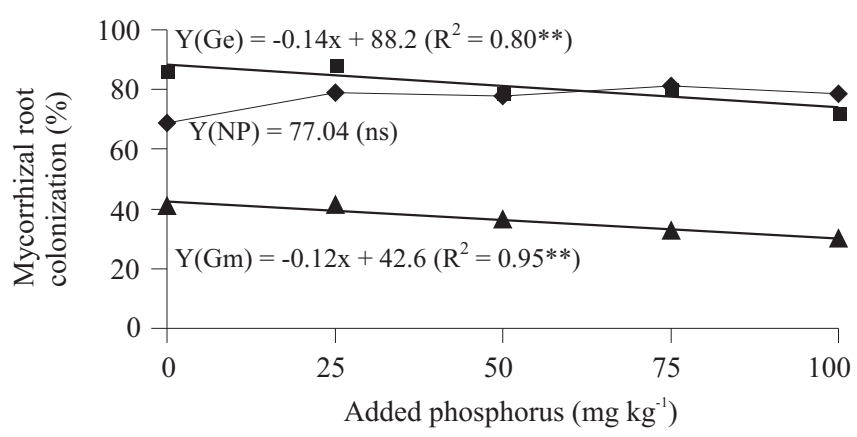

Figure 3. Mycorrhizal root colonization of mangaba tree inoculated with AM, in a sterilized soil with increasing levels of phosphorus. Native pool, NP ( $)$; Glomus etunicatum, Ge (ם); Gigaspora margarita, Gm (ム). nsNonsignificant. **Significant regressions at $1 \%$ probability level. the reported ones for mangaba tree (Costa et al., 2005), especially in the mycorrhizal plants at higher P levels. Woody species adapted to low-fertility soils, like mangaba, usually have low growth rates, and are often very conservative in their use of nutrients. These species have low rates of tissue turnover and high degrees of nutrient reallocation, which contributes to a higher overall $\mathrm{P}$ utilization efficiency (Zangaro et al., 2007).

This study demonstrated that mangaba is very dependent on mycorrhiza, regardless the inoculum source, indicating that mangaba tree could not survive in natural low-fertility environments without mycorrhizal symbiosis. In addition, not only the inoculation with sole purified mycorrhizal species, but also native AM pool can anticipate the plantlets, in nurseries of mangaba seedlings, which can be transplanted earlier to the field. The plant response to AM inoculation is always dependent on plant species, AM fungi and environment interactions, which should be previously tested in each case.
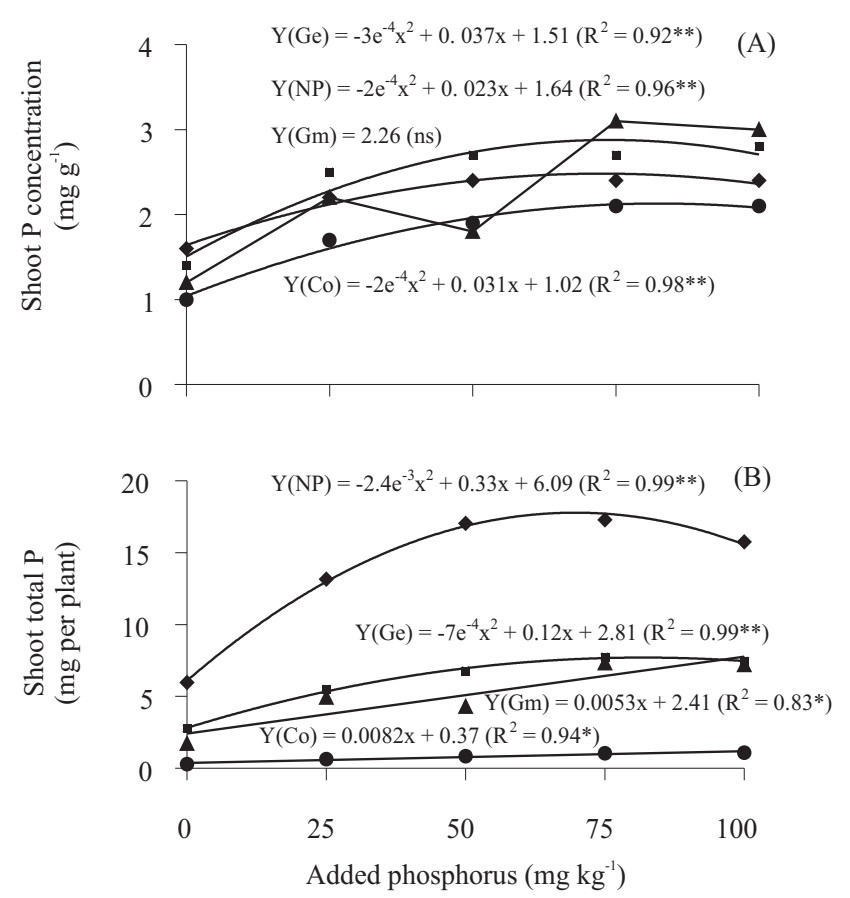

Figure 4. Shoot phosphorus concentration (A) and shoot total phosphorus (B), in mangaba tree grown in a sterilized soil with increasing levels of phosphorus and mycorrhizal treatments. Native pool, NP ( $)$; Glomus etunicatum, Ge (ם); Gigaspora margarita, $\mathrm{Gm}(\mathbf{\Lambda})$; and nonmycorrhizal mangaba

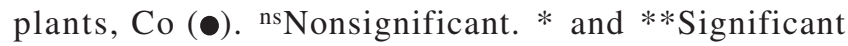
regressions at 5 and $1 \%$ probability level, respectively. 


\section{Conclusions}

1. Mangaba presents very high relative micorrhizal dependency, regardless of soil phosphorus status and micorrhizal inoculum, but the degree of dependency varies according to these variables.

2. Mangaba growth is more responsive to mycorrhizal inoculation than to phosphorus addition to growth substrate.

3. Mangaba tree is very little responsive to phosphorus under nonmycorrhizal condition.

\section{Acknowledgements}

To Conselho Nacional de Desenvolvimento Científico e Tecnológico, for scholarship; to Dr. José Oswaldo Siqueira (Ufla, Lavras), for kind supply of mycorrhizal inocula (G. margarita and G. etunicatum); to Gilson Moura Filho, for help with the statistical analysis; to Arlindo Rodrigues, for critical review of the manuscript.

\section{References}

AGUIAR FILHO, S.P.; BOSCO, J.; ARAÚJO, I.A. A mangabeira (Hancornia speciosa): domesticação e técnica de cultivo. João Pessoa: Emepa, 1998. 26p. (Emepa. Documentos, 24).

CAVALCANTE, U.M.T.; MAIA, L.C.; COSTA, C.M.C.; SANTOS, F.V. Mycorrhizal dependency of passion fruit (Passiflora edulis $\mathrm{f}$. flavicarpa). Fruits, v.56, p.317-324, 2001.

COSTA, C.M.C.; CAVALCANTE, U.M.T.; GOTO, B.T.; SANTOS, V.F.; MAIA, L.C. Fungos micorrízicos arbusculares e adubação fosfatada em mudas de mangabeira. Pesquisa Agropecuária Brasileira, v.40, p.225-232, 2005.

COSTA, C.M.C.; CAVALCANTE, U.M.T.; LIMA JÚNIOR, M.R.; MAIA, L.C. Inoculum density of arbuscular mycorrhizal fungi needed to promote growth of Hancornia speciosa Gomes seedlings. Fruits, v.56, p.247-254, 2003.

FAO. Soil map of the world: revised legend with corrections. Rome: FAO, Unesco; Wageningen: ISRIC, 1994. 140p. (World Resources Report, 60).

GIOVANETTI, M.; MOSSE, B. An evaluation of techniques for measuring vesicular-arbuscular mycorrhizal infection in roots. New Phytologist, v.84, p.489-500, 1980.

GRAHAM, J.H. Assessing costs of arbuscular mycorrhizal symbiosis in agroecosystems. In: PODILA, G.P.; DOUDS, D.D. (Ed.). Current advances in mycorrhizae research. Saint Paul: APS Press, 2000. p.127-140.

HABTE, M.; MANJUNATH, A. Categories of vesicular-arbuscular mycorrhizal dependency of hostspecies. Mycorrhiza, v.1, p.3-12,1991.
HART, M.M.; READER, R.J. Taxonomic basis of variation in the colonization strategy of arbuscular mycorrhizal fungi. New Phytologist, v.153, p.335-344, 2002.

KORMANIK, P.P.; McGRAW, A.C. Quantification of vesiculararbuscular mycorrhizae in plant roots. In: SCHENK, N.C. (Ed.). Methods and principles of mycorrhizal research. Saint Paul: American Phytopathological Society, 1982. p.37-46.

MURPHY, J.; RILEY, J.P. A modified single solution method for the determination of phosphate in natural waters. Analytical Chimica Acta, v.27, p.31-36, 1962.

NOGUEIRA, M.A.; CARDOSO, E.J.B.N. Phosphorus availability changes the internal and external endomycorrhizal colonization and affects symbiotic effectiveness. Scientia Agricola, v.64, p.295-300, 2007.

NOGUEIRA, M.A.; CARDOSO, E.J.B.N. Plant growth and phosphorus uptake in mycorrhizal 'Rangpur' lime seedlings under different levels of phosphorus. Pesquisa Agropecuária Brasileira, v.41, p.93-99, 2006.

PARENTE, T.V.; CARMONA, R. Preservação do poder germinativo de sementes de mangaba (Hancornia speciosa Gomes) em diferentes meios de armazenamento. Revista Brasileira de Fruticultura, v.10, p.71-76, 1988.

PHILLIPS, J.M.; HAYMAN, D.S. Improved procedures for clearing roots and staining parasitic and vesicular-arbuscular mycorrhizal fungi for rapid assessment of infection. Transactions of the British Mycological Society, v.55, p.158-161, 1970.

PLENCHETTE, C.; FORTIN, J.A.; FURLAN, V. Growth responses of several plant species to mycorrhizae in a soil of moderate P-fertility. I. Mycorrhizal dependency under field conditions. Plant and Soil, v.70, p.199-209, 1983.

SANO, S.M.; FONSECA, C.E.L. Avaliação de progênies de mangabeira do Cerrado. Planaltina: Embrapa Cerrados, 2003. 16p. (Embrapa Cerrados. Boletim de Pesquisa e Desenvolvimento, 96).

SAS INSTITUTE. SAS: user's guide version $6.11 .4^{\text {th }}$ ed. Cary: SAS Institute, 1996.

TRISTÃO, F.S.M.; ANDRADE, S.A.L.; SILVEIRA, A.P.D. Fungos micorrízicos arbusculares na formação de mudas de cafeeiro, em substratos orgânicos comerciais. Bragantia, v.65, p.649-658, 2006.

VAN DER REIJDEN, E.W.; KUYPER, T.W. Does origin of mycorrhizal fungus or mycorrhizal plant influence effectiveness of the mycorrhizal symbiosis? Plant and Soil, v.230, p.161-174, 2001.

ZANGARO, W.; NISHIDATE, F.R.; CAMARGO, F.R.S.; ROMAGNOLI, G.G.; VANDRESSEN, J. Relationships among arbuscular mycorrhizas, root morphology and seedling growth of tropical native woody species in Southern Brazil. Journal of Tropical Ecology, v.21, p.529-540, 2005.

ZANGARO, W.; NISHIDATE, F.R.; VANDRESEN, J.; ANDRADE, G.; NOGUEIRA, M.A. Root mycorrhizal colonization and plant responsiveness are related to root plasticity, soil fertility and successional status of native woody species in Southern Brazil. Journal of Tropical Ecology, v.23, p.53-62, 2007.

Received on February 11, 2008 and accepted on June 30, 2008 